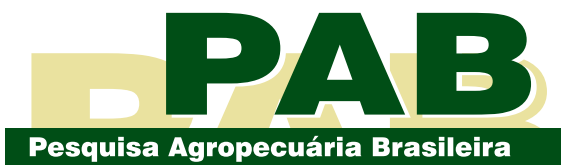

ISSN 1678-3921

Journal homepage: www.embrapa.br/pab

For manuscript submission and journal contents, access: www.scielo.br/pab
Soil Science/ Original Article

\section{Potassium application for sugarcane in a sandy loam Oxisol of the Brazilian Cerrado}

\begin{abstract}
The objective of this work was to evaluate rates and methods of potassium application for plant cane (Saccharum spp.) grown in a dystrophic Typic Haplustox with a sandy loam texture in the Brazilian Cerrado. The experiment was carried out in the municipality of Aporé, in the state of Goiás, using the RB92579 sugarcane variety. The experimental design was randomized complete blocks, with three replicates, in a $5 \times 3$ factorial arrangement, with five potassium rates $\left(0,60,110,160\right.$, and $200 \mathrm{~kg} \mathrm{ha}^{-1} \mathrm{~K}_{2} \mathrm{O}$ as potassium chloride) and three application methods $(100 \%$ at the bottom of the planting furrow and covered with soil, $100 \%$ side-dressed on the sugarcane rows 60 days after planting, and 50\% in the planting furrow and $50 \%$ sidedressed). The amount of potassium in the stalks in the control treatment was greater than that of the potassium stock extractable by Mehlich-1 in the $0-60 \mathrm{~cm}$ soil layer. Stalk and sugar yields increase linearly with potassium rates, approximately $20 \%$ with $200 \mathrm{~kg} \mathrm{ha}^{-1} \mathrm{~K}_{2} \mathrm{O}$ compared with the control treatment (without potassium). Potassium content in stalks also increases with potassium rates. There is no significant effect of the potassium application methods on stalk and sugar yields and on cane quality variables.
\end{abstract}

Index terms: Saccharum, potassium fertilization management, stalk yield, sugar yield.

\section{Aplicação de potássio para cana-de-açúcar em Latossolo de textura franco-arenosa do Cerrado brasileiro}

Resumo - O objetivo deste trabalho foi avaliar doses e métodos de aplicação de potássio em cana-planta (Saccharum spp.) cultivada em Latossolo VermelhoAmarelo distrófico de textura franco-arenosa, em Cerrado brasileiro. O experimento foi realizado no município de Aporé, no estado de Goiás, tendo-se utilizado a variedade de cana-de-açúcar RB92579. O delineamento experimental foi de blocos ao acaso, com três repetições, em arranjo fatorial $5 \times 3$, com cinco doses de potássio $\left(0,60,110,160\right.$ e $200 \mathrm{~kg} \mathrm{ha}^{-1}$ de $\mathrm{K}_{2} \mathrm{O}$ na forma de cloreto de potássio) e três métodos de aplicação (100\% no fundo do sulco de plantio e coberto com solo, $100 \%$ em cobertura nas fileiras da cana-de-açúcar 60 dias após o plantio, e $50 \%$ no sulco de plantio e $50 \%$ em cobertura). A quantidade de potássio nos colmos do tratamento controle foi superior à do estoque de potássio extraível por Mehlich-1 na camada de 0-60 $\mathrm{cm}$ do solo. As produtividades de colmos e de açúcar aumentam linearmente com as doses de potássio, aproximadamente $20 \%$ com $200 \mathrm{~kg} \mathrm{ha}^{-1} \mathrm{de}_{2} \mathrm{O}$ em comparação ao tratamento controle (sem potássio). O teor de potássio nos colmos também aumenta com as doses de potássio. Não há efeito significativo dos métodos de aplicação de potássio na produtividade de colmos e de açúcar e nas variáveis de qualidade da cana.

Termos para indexação: Saccharum, manejo da adubação potássica, rendimento de colmo, rendimento de açúcar. 


\section{Introduction}

Sugarcane (Saccharum spp.) production has shown a significant growth in the Midwestern region of Brazil during the last two decades, going from 24 to 144 million tons of cane in 2020 (IBGE, 2020). The expansion of sugarcane has occurred in soils with different textures, including coarse-textured soils, such as Neossolos Quartzarênicos (Quartzipsamments), which account for $15 \%$ of the Cerrado biome, and Latossolos (largely Oxisols) with a sandy-loam texture.

Coarse-textured soils are classified in terms of the clay contents and textural changes in their profile, which distinguishes Neossolos, Latossolos, and Argissolos in the first categorical level of the Brazilian Soil Classification System (Santos et al., 2018). Most of these soils are flat or with gentle slopes, which favors mechanization. However, when originally under Cerrado vegetation, these soils are characterized by a low-water retention capacity, low cation exchange capacity (CEC), low soil organic matter content, high aluminum saturation, low sum of bases and base saturation, and high susceptibility to erosion due to a low cohesion between soil particles and a low aggregate stability (Donagemma et al., 2016).

In most sugar mills in the region, high rates of potassium are applied to the plant cane, in the planting furrow, using potassium chloride, a fertilizer with a high salt index (Raij, 2011). In coarse-textured soils, this management, associated with a low rainfall during crop establishment, might lead the plant to failure in establishing its root system and to difficulties in sprouting, whereas intense rainfall leads to leaching since sandy soils have a low CEC and the preference for potassium adsorption is low (Kaminski et al., 2010; Garcia et al., 2015; Ucker et al., 2016; Luz et al., 2017). Another common practice is splitting (side-dressing) potassium rates, which is justified by the facts that potassium salts are highly soluble and this nutrient exhibits high mobility in these soils, rapidly reaching the root zone (Lana et al., 2004; Raij, 2011).

Most studies involving potassium rates in sugarcane have been carried out under different soil and climate conditions, as well as using different varieties (Reis Junior, 2001; Lana et al., 2004; Rossetto et al., 2004, 2010b; Otto et al., 2010; Flores et al., 2014, 2020; Pancelli et al., 2015). However, there are few studies on sandy soils planted with more recent varieties, particularly regarding application methods of potassium for sugarcane under green-cane harvesting, a condition that can affect crop responses to potassium fertilization management (Luz et al., 2017).

Therefore, the advance of sugarcane cultivation in sandy soils in the Midwestern region of Brazil still lacks scientific information not only on the management of potassium fertilization, but also on other nutrients and correction practices (Donagemma et al., 2016).

The objective of this work was to evaluate rates and methods of potassium application for plant cane grown in a dystrophic Typic Haplustox with a sandy loam texture in the Brazilian Cerrado.

\section{Materials and Methods}

The experiment was carried out at the farm of Agropecuaria Thermotec Ltda., located in the municipality of Aporé, in the state of Goiás, Brazil $\left(52^{\circ} 03^{\prime} 52^{\prime \prime} \mathrm{N}, 18^{\circ} 33^{\prime} 10^{\prime \prime} \mathrm{S}\right.$, at $699 \mathrm{~m}$ altitude). The soil was classified as a Latossolo Vermelho-Amarelo distrófico according to the Brazilian Soil Classification System (Santos et al., 2018), i.e., as a dystrophic Typic Haplustox. By Köppen-Geiger's classification, the climate is Cwa, humid temperate with a dry winter and a hot summer. The area planted with sugarcane was once a pasture for extensive livestock production. Prior to the experiment, sugarcane was cropped for eight years, and the last ratoon crop was harvested on April 2015 as green cane without straw burning. The area was kept as fallow land (with weeds) up to March 2016.

Soil sampling to characterize the experimental area was carried out on October 2015 based on the methodology of Rein et al. (2015), at the following depths: 0 to $0.20,0.20$ to 0.40 , and 0.40 to $0.60 \mathrm{~m}$. A composite sample of 100 subsamples was taken at 20 random points, each one comprising five positions in relation to the sugarcane row, one on the row and two on each side of the row up to half of the interrow spacing. Soil samples were analyzed according to Silva (2009). Precipitation and temperature data throughout the experiment are shown in Figure 1.

Based on the results of the soil chemical analysis (Table 1), soil acidity correction and fertilization were conducted according to the technical recommendations for the Cerrado region (Sousa \& Lobato, 2004). The following operations were carried in the experimental area, in this order: desiccation of sugarcane after the last ratoon cycle; subsoiling at a depth of 0.45 
$\mathrm{m}$; application of limestone, gypsum, and corrective phosphorus fertilization; primary tillage with a heavy disk harrow at a depth of $0.20 \mathrm{~m}$, followed by light harrowing; planting-furrow opening at a depth of $0.20 \mathrm{~m}$ and manual application of fertilizers, covered with soil at the bottom of the furrow; manual distribution of the seed cane in March 2016; in-furrow spray application of insecticide and fungicide $\left(0.2 \mathrm{~kg} \mathrm{ha}^{-1}\right.$ Fipronil a.i. and $0.5 \mathrm{~L} \mathrm{ha}^{-1}$ Pyraclostrobin $250 \mathrm{~g} \mathrm{~L}^{-1}$ a.i., respectively), followed by covering the seed cane with soil; application of pre-emergence herbicide $\left(1.5 \mathrm{~L} \mathrm{ha}^{-1}\right.$ Tebuthiuron $500 \mathrm{~g} \mathrm{~L}^{-1}$ a.i.); side-dress fertilization 60 days after planting; and manual harvesting on May 2017. Dolomitic limestone (effective calcium carbonate equivalent of $85 \%$ ), phosphogypsum (to supply sulfur and improve the root environment in the subsurface layers), and corrective phosphorus (monoammonium phosphate) were broadcast at the rates of $1.37 \mathrm{Mg} \mathrm{ha}^{-1}$, $1.35 \mathrm{Mg} \mathrm{ha}^{-1}$, and $85 \mathrm{~kg} \mathrm{ha}^{-1} \mathrm{P}_{2} \mathrm{O}_{5}$, respectively.

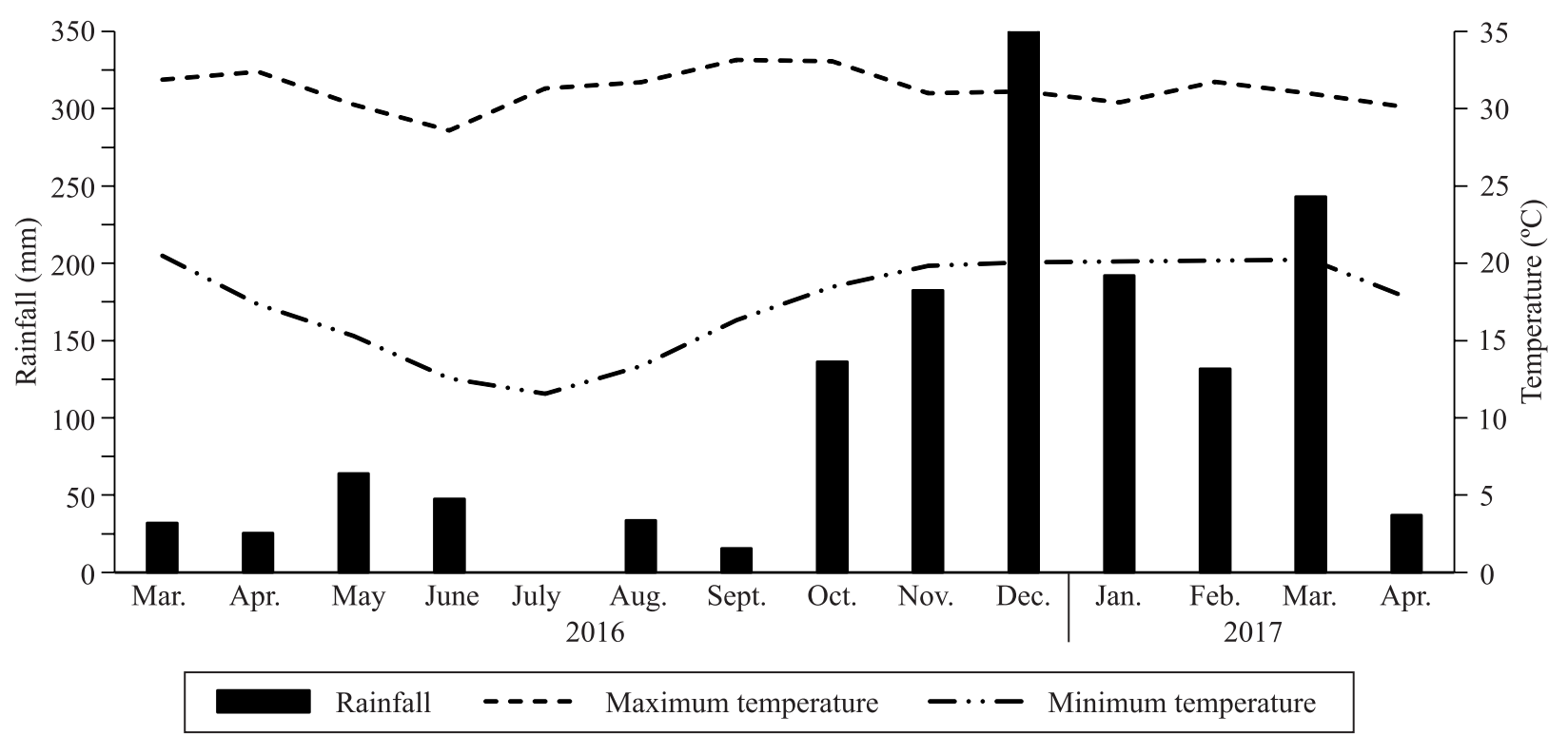

Figure 1. Rainfall and maximum and minimum temperatures during the plant cane (Saccharum spp.) cycle, in the municipality of Aporé, in the state of Goiás, Brazil. Source: Energética Serranópolis Ltda. (2017).

Table 1. Chemical properties and texture of the studied Latossolo Vermelho-Amarelo distrófico (dystrophic Typic Haplustox), at different soil depths, before soil correction and the establishment of the experiment with the cultivation of plant cane (Saccharum spp.), in the municipality of Aporé, in the state of Goiás, Brazil, in 2015 ${ }^{(1)}$.

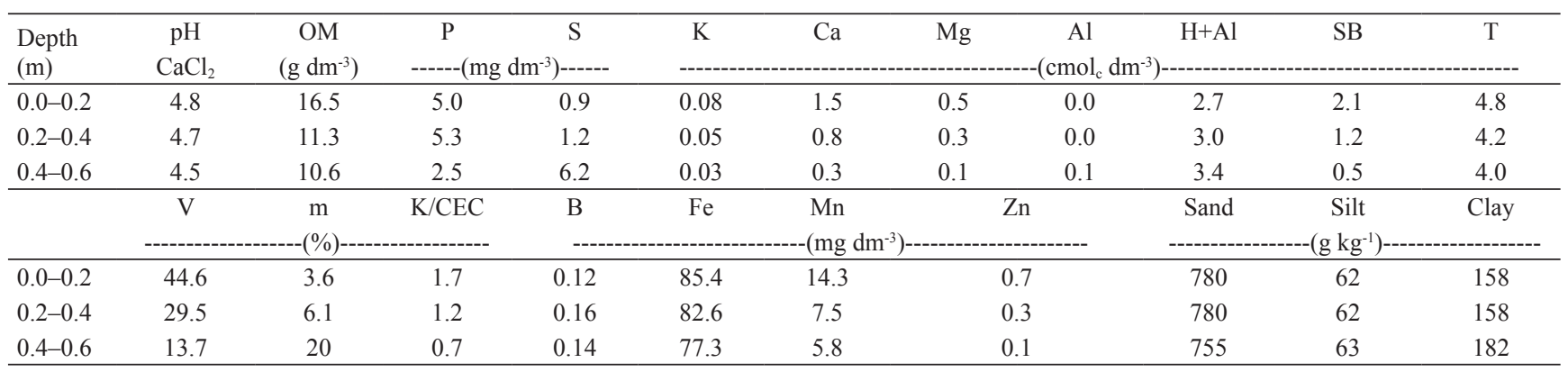

(1) $1.0 \mathrm{~mol} \mathrm{~L}^{-1} \mathrm{KCl}$ as extractant for calcium, magnesium, and aluminum; Melich-1 as extractant for potassium, phosphorus, copper, iron, manganese, and zinc; $1.0 \mathrm{~mol} \mathrm{~L}^{-1}$ ammonium acetate + acetic acid solution for extraction of sulfur; hot water for boron extraction; sodium dichromate for extraction of organic matter $(\mathrm{OM})$; calcium acetate at $\mathrm{pH} 7.0$ for titratable acidity $(\mathrm{H}+\mathrm{Al})$; and sodium hydroxide $(\mathrm{NaOH})$ for clay, silt, and sand dispersion. $\mathrm{SB}$, sum of bases; $\mathrm{T}$, cation exchange capacity (CEC) at $\mathrm{pH} 7.0 ; \mathrm{V}$, base saturation; and $\mathrm{m}$, aluminum saturation. 
Monoammonium phosphate was applied at $21 \mathrm{~kg} \mathrm{ha}^{-1}$ $\mathrm{N}$ and $100 \mathrm{~kg} \mathrm{ha}^{-1} \mathrm{P}_{2} \mathrm{O}_{5}$ to the entire area of the experiment, at the bottom of the planting furrow. A total of $60 \mathrm{~kg} \mathrm{ha}^{-1}$ nitrogen (ammonium sulfate, 20\% nitrogen), $2.1 \mathrm{~kg} \mathrm{ha}^{-1}$ boron (boric acid, 17\% boron), and $1.5 \mathrm{~kg} \mathrm{ha}^{-1}$ zinc (zinc sulfate, $20 \%$ zinc) was sidedressed throughout all the experimental area on the sugarcane row 60 days after planting, simultaneously to soil leveling on the interrow, a practice known as "quebra-lombo".

The treatments were distributed in experimental plots in three randomized complete blocks, in a $5 \times 3$ factorial arrangement, to evaluate five potassium rates $\left(0,60,110,160\right.$, and $200 \mathrm{~kg} \mathrm{ha}^{-1} \mathrm{~K}_{2} \mathrm{O}$ as potassium chloride) and three application methods (100\% at the bottom of the planting furrow and covered with soil, $100 \%$ side-dressed on the sugarcane rows 60 days after planting, and $50 \%$ in the planting furrow and $50 \%$ side-dressed). The plots consisted of five $10 \mathrm{~m}$ rows, with $1.5 \mathrm{~m}$ spacing between rows, totaling $75 \mathrm{~m}^{2}$. Crop and soil evaluations were carried out by hand in a net area of $45 \mathrm{~m}^{2}$, comprising the three central rows, excluding $1 \mathrm{~m}$ of the borders.

The evaluated sugarcane (Saccharum spp.) variety was RB92579, which is among the five most planted in the Midwestern-Southern sugarcane planting region of Brazil, as well as in the state of Goiás (Braga Junior et al., 2019).

Tiller population (number of tillers per meter row) was evaluated at 90 and 270 days after planting (DAP). At the end of the plant crop cycle (420 days), sugarcane was harvested by hand and stalks were weighed, expressed as tons of millable stalks per hectare (TCH). For the evaluations of cane quality (soluble solids, in Brix; juice apparent sucrose content, expressed as Pol; purity; cane reducing sugars content; cane apparent sucrose content, ASC; cane fiber; moisture; and cane total recoverable sugars, TRS) and cane diameter, ten stalks were randomly sampled for each plot and analyzed at the Laboratory of Technological Analysis of the Energética Serranópolis sugar mill (Serranópolis, GO, Brazil), according to the Consecana methodology (Consecana, 2006). Sugar yield was expressed as tons of total recoverable sugars per hectare (TSH).

For the assessment of the nutritional status of the sugarcane crop, a sample of ten top-visible dewlap leaves (youngest fully-expanded leaves) was collected from each plot 270 DAP, in the stalk elongation stage, during the rainy season, in December 2016. The center rib, tip, and base of the leaf blades were discarded, and approximately $20 \mathrm{~cm}$ of the central part of the leaf blade was kept for analysis, according to Raij et al. (1996).

The contents of nutrients in the stalks were analyzed in samples collected from the ten shredded and homogenized canes used for the cane quality analysis. The leaf and shredded-cane samples were oven-dried at $65^{\circ} \mathrm{C}$ until constant weight, ground, and analyzed for potassium and other nutrients according to Malavolta et al. (1997). Nutrient extraction in the stalks was computed from nutrient contents and stalk yields.

After harvest in May 2017, all plots were sampled for the analysis of potassium along the soil profile. Three subsamples were taken at $0.10 \mathrm{~m}$ from the crop row, at the depths of $0-20,20-40$, and $40-60 \mathrm{~cm}$. For this purpose, composite samples from each treatment were formed by mixing the subsamples of the three replicates.

Data were subjected to the analysis of variance, at $5 \%$ probability. The isolated effects of factors were assessed using Tukey's test, at 5\% probability, for application methods and polynomial regression for potassium rates. The Sisvar statistical software (Ferreira, 2014) was used.

\section{Results and Discussion}

None of the evaluated variables was affected by the potassium application methods. There was also no significant effect of the potassium rates on plant height and number of tillers per row meter at 90 and 270 DAP, as well as on the cane quality components (soluble solids, TRS, juice apparent sucrose content, purity, fiber, ASC, reducing sugars, and moisture) (Table 2). However, stalk (TCH) and sugar (TSH) yields and cane diameter increased linearly with the potassium rates (Figure $2 \mathrm{~A}, \mathrm{~B}$, and $\mathrm{C}$ ). In addition, leaf analysis for the assessment of the nutritional status of sugarcane showed a significant effect of potassium rates only on potassium content, which followed a quadratic trend in relation to the rates (Figure $2 \mathrm{D}$ ). Therefore, the mean leaf contents of the other nutrients were not significantly affected by the potassium rates (Table 3 ).

Potassium is the nutrient taken up in the largest amount by the sugarcane crop (Rossetto et al., 2010b), and the results of TCH and TSH highlight the positive effect of potassium, with increases of 25 and 4.3 
$\mathrm{Mg} \mathrm{ha}^{-1}$ between the control and the highest potassium rate (Figure 2), without affecting sugar content (Table 2). Linear or quadratic yield responses of sugarcane to potassium rates have been shown on sandy loam Oxisols (Lana et al., 2004; Almeida et al., 2015) and other soils in Brazil (Rossetto et al., 2004, 2010a; Otto et al., 2010; Flores et al., 2014, 2020; Pancelli et al., 2015). However, although potassium acts

Table 2. Plant height, number of tillers per meter row at 90 (NP90) and 270 (NP270) days after planting, cane total recoverable sugars (TRS), juice soluble solids (SS), juice apparent sucrose content (jASC), purity, cane fiber content (F), cane apparent sucrose content (ASC), cane reducing sugars content (RS), and moisture of plant cane (Saccharum spp.). Averages of the potassium rates $\left(0,60,110,160\right.$, and $\left.200 \mathrm{~kg} \mathrm{ha}^{-1} \mathrm{~K}_{2} \mathrm{O}\right)$ and application methods (planting furrow, side-dressed, and split).

\begin{tabular}{|c|c|c|c|c|c|c|c|c|c|c|c|}
\hline Variable $^{(1)}$ & $\begin{array}{l}\text { Plant height } \\
\text { (m) }\end{array}$ & $\begin{array}{c}\text { NP90 } \\
-\end{array}$ & $\begin{array}{c}\text { NP270 } \\
-\end{array}$ & $\begin{array}{c}\text { TRS } \\
\left(\mathrm{kg} \mathrm{Mg}^{-1}\right)\end{array}$ & SS (Brix) & jASC (pol) & Purity & $\begin{array}{c}F \\
---(\%\end{array}$ & ASC & RS & Moisture \\
\hline Mean & 3.37 & 17.0 & 11.6 & 128.7 & 17.3 & 14.9 & 86.0 & 10.6 & 12.9 & 0.6 & 72 \\
\hline CV (\%) & 3.70 & 15.0 & 6.2 & 3.3 & 2.7 & 3.8 & 1.4 & 2.2 & 3.6 & 5.8 & 1.0 \\
\hline
\end{tabular}

${ }^{(1)}$ Biometric and cane quality variables for which there was no significant effect of treatment by the F-test, at $5 \%$ probability. CV, coefficient of variation.
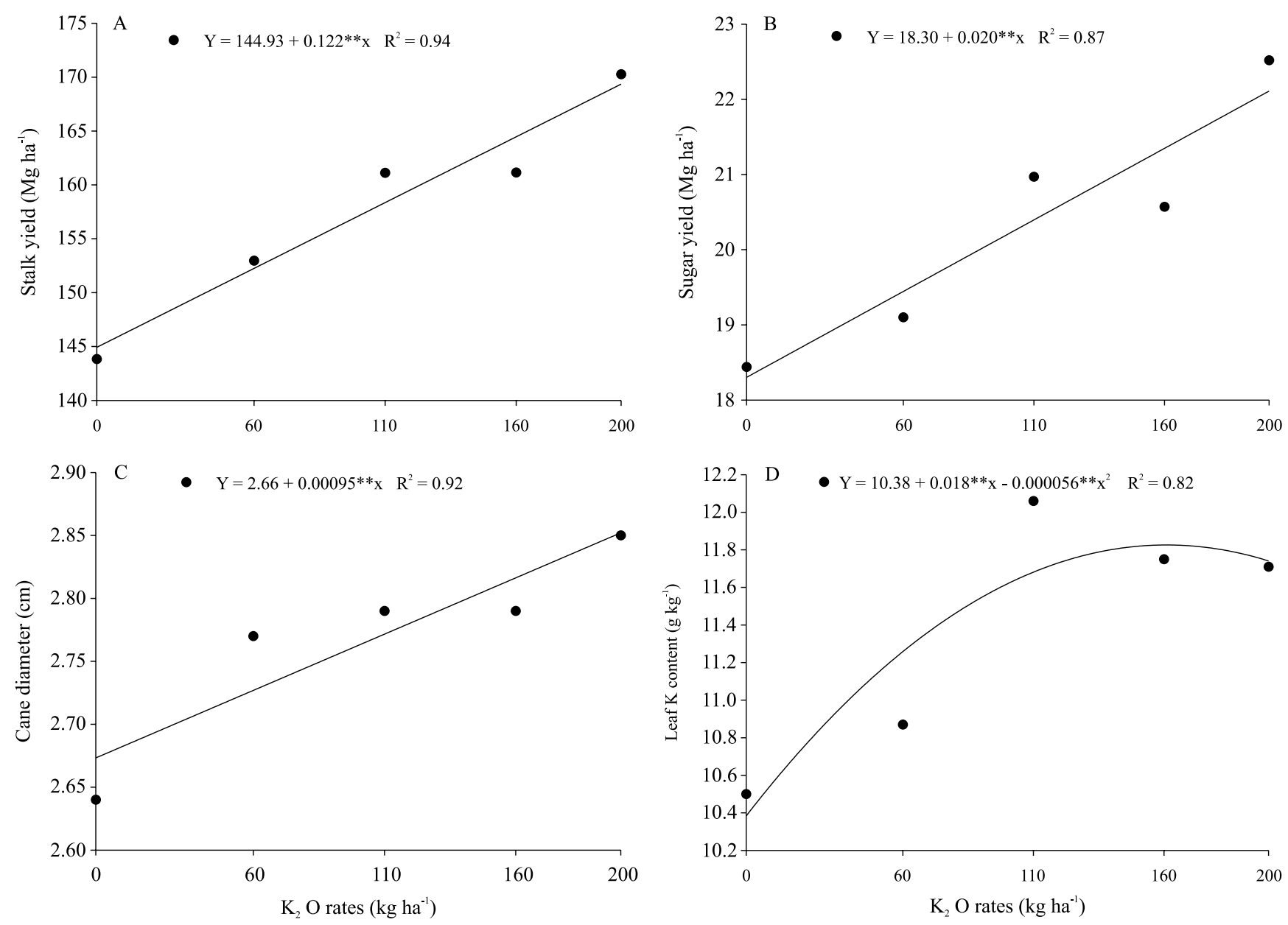

Figure 2. Stalk yield (A), sugar yield (B), cane diameter (C), and leaf potassium content (D) of plant cane (Saccharum spp.) grown with increasing potassium rates in the municipality of Aporé, in the state of Goiás, Brazil. Averages of three application methods of potassium (planting furrow, side-dressed, and split). $\mathrm{CV}$, coefficient of variation. $\mathrm{CV}_{\text {stalk yield }}=11.5 \%$, $\mathrm{CV}_{\text {sugar yield }}=11.3 \%, \mathrm{CV}_{\text {cane diameter }}=4.3 \%$, and $\mathrm{CV}_{\text {leaf K content }}=6.5 \% . * *$ Significant at $1 \%$ probability. 
in the processes of translocation and storage of sucrose in stalks (Silveira \& Crocomo, 1991), an increase in sugar contents with potassium rates is rarely observed (Orlando Filho \& Zambello Junior, 1980; Rossetto et al., 2010b).

Despite the low levels of potassium in the soil before the installation of the experiment (Table 1), the high $\mathrm{TCH}$ and TSH values for the control treatment deserve attention (Figure 2). The accumulation of $137 \mathrm{~kg} \mathrm{ha}^{-1}$ $\mathrm{K}$ in stalks in the control treatment (Figure $3 \mathrm{~A}$ ) was higher than the Mehlich-1 extractable potassium stock in the 0-60 cm layer (Table 1), computed as $125 \mathrm{~kg} \mathrm{ha}^{-1}$. An extra amount of potassium above $100 \mathrm{~kg} \mathrm{ha}^{-1}$ is expected in sugarcane straw (green tops and dry leaves) for the stalk yield of $145 \mathrm{Mg} \mathrm{ha}^{-1}$ in the control treatment (Otto et al., 2019).

Some factors may have contributed to this result: absorption of non-exchangeable forms of potassium as primary and secondary minerals (Otto et al., 2010; Raij, 2011); potassium cycling by the sugarcane straw from the last ratoon cycle harvested without burning (Rossetto et al., 2010b), largely not accounted for by soil sampling at the beginning of the rainy season in October 2015; sugarcane deep-rooting pattern and soil correction practices favoring root growth, as well as exploration of the soil profile for nutrients much below the sampled layers; and high genetic potential of the assessed variety and adequate distribution of rainfall and temperature (Figure 1), ensuring a proper plant development, both factors favoring high yields for all treatments. Low or even no cane yield increases with potassium application in soils with low potassium contents have been reported in other single-year experiments in Brazil (Rossetto et al., 2010a).

Deriving the equation that relates potassium content to the applied rates and equaling it to zero (Figure 2 D),

Table 3. Leaf nutrient content of the plant cane (Saccharum spp.) averaged over all potassium rates $(0,60,110,160$, and 200 $\mathrm{kg} \mathrm{ha}^{-1} \mathrm{~K}_{2} \mathrm{O}$ ) and application methods (planting furrow, side-dressed, and split).

\begin{tabular}{|c|c|c|c|c|c|c|c|c|c|c|}
\hline \multirow{2}{*}{ Nutrient $^{(1)}$} & $\mathrm{N}$ & $\mathrm{P}$ & $\mathrm{Ca}$ & $\mathrm{Mg}$ & $\mathrm{S}$ & B & $\mathrm{Cu}$ & $\mathrm{Fe}$ & $\mathrm{Mn}$ & $\mathrm{Zn}$ \\
\hline & \multicolumn{10}{|c|}{ 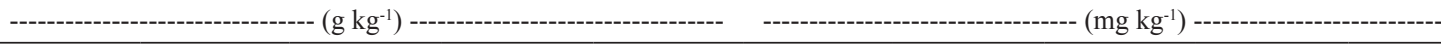 } \\
\hline Mean & 20 & 1.8 & 3.0 & 1.3 & 1.5 & 4 & 6.3 & 62 & 24 & 18 \\
\hline CV (\%) & 5.7 & 8.4 & 10.6 & 11 & 6.4 & 19 & 12 & 8.2 & 17 & 15 \\
\hline
\end{tabular}

${ }^{(1)}$ Leaf nutrients for which there was no significant effect of treatment by the F-test, at 5\% probability. CV, coefficient of variation.
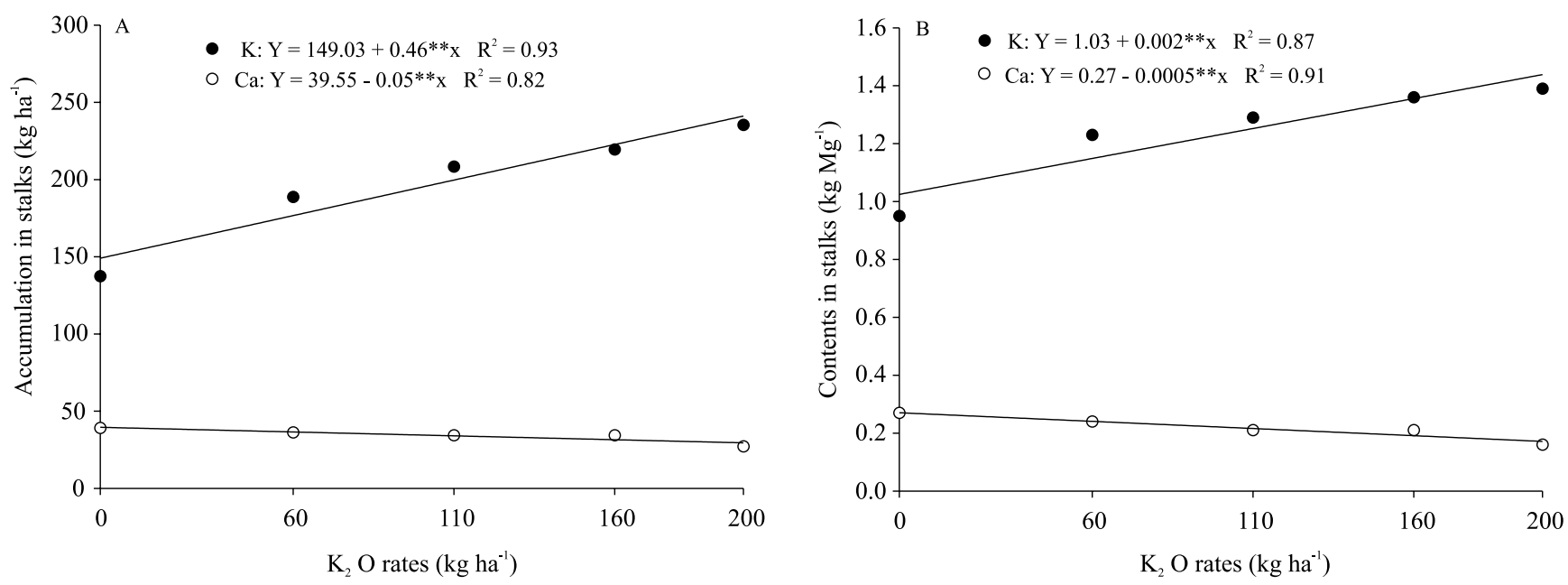

Figure 3. Accumulation of potassium and calcium in stalks (A) and contents of potassium and calcium in fresh stalks (B) of plant cane (Saccharum spp.) grown with increasing potassium rates in the municipality of Aporé, in the state of Goiás, Brazil. Averages of three application methods of potassium (planting furrow, side-dressed, and split). CV, coefficient of variation. $\mathrm{CV}_{\mathrm{K} \text { accumulation in stalks }}=15 \%, \mathrm{CV}_{\mathrm{Ca} \text { accumulation in stalks }}=14 \%, \mathrm{CV}_{\mathrm{K} \text { contents in stalks }}=12 \%$, and $\mathrm{CV}_{\mathrm{Ca} \text { contents in stalks }}=19 \%$. $* *$ Significant at $1 \%$ probability. 
the rate of $160 \mathrm{~kg} \mathrm{ha}^{-1} \mathrm{~K}_{2} \mathrm{O}$ was obtained, which provided the maximum potassium leaf content of $11.7 \mathrm{~g} \mathrm{~kg}^{-1}$. According to Raij et al. (1996), the potassium leaf contents for all treatment rates are within the optimum range of 10-16 $\mathrm{g} \mathrm{kg}^{-1}$ (Table 3). The other nutrients are also within the optimum range, except boron, despite being side-dressed, which should be between 10-30 mg kg-1 (Raij et al., 1996); however, no symptoms of boron deficiency were observed.

Potassium content $\left(\mathrm{kg} \mathrm{Mg}^{-1}\right)$ and accumulation $\left(\mathrm{kg} \mathrm{ha}^{-1}\right)$ in fresh millable stalks increased with the potassium rates (Figure 3). The content in stalks ranged from 1.03 to $1.43 \mathrm{~kg} \mathrm{Mg}^{-1} \mathrm{~K}$, respectively, for the control treatment and the highest potassium rate. These values are close to the average and within the range of potassium contents of a recent compilation of the nutrient contents of sugarcane stalks, showing an average of $1.19 \mathrm{~kg} \mathrm{Mg}^{-1} \mathrm{~K}$ for soils with potassium contents below $0.3 \mathrm{cmol}_{\mathrm{c}} \mathrm{dm}^{-3}$, with values ranging from 0.9 to $2.0 \mathrm{~kg} \mathrm{Mg}^{-1} \mathrm{~K}$ (Otto et al., 2019).

Potassium accumulation in stalks ranged from 149 to $242 \mathrm{~kg} \mathrm{ha}^{-1}$. The later quantities are greater than the applied potassium rates of 0 to $200 \mathrm{~kg} \mathrm{~K}_{2} \mathrm{O}$ or 166 $\mathrm{kg} \mathrm{ha}^{-1} \mathrm{~K}$, as well as than the initial amount in the soil extracted by the Mehlich-1 solution $\left(0.05 \mathrm{~mol} \mathrm{~L}^{-1} \mathrm{HCl}\right.$ $+0.0125 \mathrm{~mol} \mathrm{~L}^{-1} \mathrm{H}_{2} \mathrm{SO}_{4}$ ) before the installation of the experiment (Table 1), which corresponds to $151 \mathrm{~kg} \mathrm{ha}^{-1}$ $\mathrm{K}_{2} \mathrm{O}$ in the $0-60 \mathrm{~cm}$ layer. These data reinforce the somewhat higher initial plant available contents of potassium in the soil and/or previous sugarcane trash, not shown by the chemical analysis of the $0-60 \mathrm{~cm}$ layers before the establishment of the experiment (Table 1).

Stalk and sugar yields (Figure $2 \mathrm{~A}$ and B), leaf potassium contents (Figure $2 \mathrm{D}$ ), and stalk potassium accumulation and contents (Figure $3 \mathrm{~A}$ and $\mathrm{B}$ ) are indicative that potassium was not provided in excess, which would lead to luxury consumption. Leite et al. (2016) observed luxury consumption of the nutrient by sugarcane, with contents in stalks of 2.03 and $5.16 \mathrm{~kg} \mathrm{Mg}^{-1} \mathrm{~K}$, respectively, in soils with low and high potassium contents. Luz et al. (2017) referred to studies that reported an average content of $2.12 \mathrm{~kg} \mathrm{Mg}^{-1}$ $\mathrm{K}$ in stalks, with no values lower than the potassium contents obtained in the present study.

Unlike potassium, calcium content and accumulation in stalks slightly decreased with the potassium rates despite the application of limestone (Figure 3), suggesting a competitive interaction between potassium and calcium in the plant uptake process. Calcium leaf content, however, was not affected by the potassium treatments (Table 3). Coleti et al. (2006) evaluated calcium extraction by a plant cane of two varieties in an Ultisol and found a mean of $0.21 \mathrm{~kg} \mathrm{Mg}^{-1} \mathrm{Ca}$ in the stalks, a value close to the one obtained in the present study. When assessing the limepotassium interaction in a study with six experiments in different regions of the state of São Paulo, Brazil, Rossetto et al. (2004) detected little interdependence between the investigated factors. However, Luz et al. (2017) cited several studies that found a mean extraction of $0.67 \mathrm{~kg} \mathrm{Mg}^{-1} \mathrm{Ca}$ from stalks, a value three times higher than the one of the present study. The contents and accumulation of other nutrients in the stalks were not significantly affected by the potassium rates, and the averages of all treatments are presented in Table 4.

Potassium contents in the $0-60 \mathrm{~cm}$ soil profile for all treatments after plant cane harvesting are shown in Table 5. The obtained potassium contents are low and even lower when compared with the initial

Table 4. Nutrient accumulation and content in fresh stalks of the plant cane (Saccharum spp.) averaged over all potassium rates $\left(0,60,110,160\right.$, and $\left.200 \mathrm{~kg} \mathrm{ha}^{-1} \mathrm{~K}_{2} \mathrm{O}\right)$ and application methods (planting furrow, side-dressed, and split).

\begin{tabular}{|c|c|c|c|c|c|c|c|c|c|}
\hline \multirow[t]{2}{*}{ Nutrient $^{(1)}$} & $\mathrm{N}$ & $\mathrm{P}$ & $\mathrm{Mg}$ & $\mathrm{S}$ & B & $\mathrm{Cu}$ & $\mathrm{Fe}$ & $\mathrm{Mn}$ & $\mathrm{Zn}$ \\
\hline & & ----- & ) ----- & --- & & 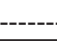 & $--(\mathrm{g}$ ha & 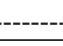 & ----- \\
\hline & \multicolumn{9}{|c|}{ Accumulation in stalks } \\
\hline Mean & 194 & 13 & 46 & 28 & 48 & 96 & 3,539 & 642 & 427 \\
\hline \multirow[t]{3}{*}{$\mathrm{CV}(\%)$} & 17 & 19 & 12 & 19 & 29 & 30 & 26 & 20 & 27 \\
\hline & \multicolumn{9}{|c|}{ Content in fresh stalks } \\
\hline & - & $-----\cdot-$ & $\left.\mathrm{g}^{-1}\right)--$ & - & - & - & $\left(\mathrm{g} \mathrm{Mg}^{-1}\right.$ & 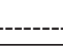 & - \\
\hline Mean & 1.23 & 0.08 & 0.29 & 0.17 & 0.3 & 0.6 & 22 & 4.0 & 2.7 \\
\hline $\mathrm{CV}(\%)$ & 9.6 & 16 & 8 & 15 & 25 & 26 & 23 & 19 & 21 \\
\hline
\end{tabular}

(1)Nutrients for which there was no significant effect of treatment by the F-test, at $5 \%$ probability. CV, coefficient of variation. 
Table 5. Potassium content in the soil at different depths after plant cane (Saccharum spp.) harvesting for all potassium rates $\left(0,60,110,160\right.$, and $\left.200 \mathrm{~kg} \mathrm{ha}^{-1} \mathrm{~K}_{2} \mathrm{O}\right)$ and application methods in the municipality of Aporé, in the state of Goiás, Brazil, in 2017.

\begin{tabular}{|c|c|c|c|c|c|}
\hline \multirow[t]{2}{*}{ Application method } & \multicolumn{5}{|c|}{ Potassium content $\left(\mathrm{cmol}_{\mathrm{c}} \mathrm{dm}^{-3}\right)$} \\
\hline & 0 & 60 & 110 & 160 & 200 \\
\hline & \multicolumn{5}{|c|}{$0.0-0.2 \mathrm{~m}$} \\
\hline Furrow & 0.03 & 0.04 & 0.04 & 0.03 & 0.06 \\
\hline Side-dressed & 0.04 & 0.04 & 0.03 & 0.05 & 0.03 \\
\hline Split & 0.03 & 0.03 & 0.03 & 0.04 & 0.03 \\
\hline \multicolumn{6}{|c|}{$0.2-0.4 \mathrm{~m}$} \\
\hline Furrow & 0.02 & 0.02 & 0.02 & 0.02 & 0.03 \\
\hline Side-dressed & 0.02 & 0.02 & 0.02 & 0.02 & 0.02 \\
\hline Split & 0.02 & 0.02 & 0.03 & 0.02 & 0.02 \\
\hline \multicolumn{6}{|c|}{$0.4-0.6 \mathrm{~m}$} \\
\hline Furrow & 0.01 & 0.02 & 0.02 & 0.01 & 0.01 \\
\hline Side-dressed & 0.02 & 0.01 & 0.01 & 0.02 & 0.02 \\
\hline Split & 0.02 & 0.01 & 0.01 & 0.01 & 0.02 \\
\hline
\end{tabular}

contents (Table 1), which is consistent with the fact that potassium accumulation in stalks (not including tops and leaves) was higher than the application rates (Figure $3 \mathrm{~A}$ ).

Contrary to expected, there were no significant effects on stalk and sugar yields as expected due to the application methods of potassium, especially for the higher potassium rates. Split and/or side-dress fertilization could reduce potassium leaching, as well as the salt concentration close to the cane seeds in the planting furrow, which could favor sprouting and crop establishment in sandy loam soils (Rossetto et al., 2010b). Lana et al. (2004) found a significant positive effect of the split application of potassium on the stalk yield of plant cane in a sandy loam Oxisol in the state of São Paulo. However, as in the present study, Otto et al. (2010) did not observe any positive effect of the split application of potassium on sugarcane yield in a sandy clay loam Oxisol.

Besides stalk and sugar yields, cane quality variables, leaf and stalk nutrient contents, and other sugar variables were also not affected by the potassium application methods.

\section{Conclusions}

1. Sugarcane (Saccharum spp.) stalk and sugar yields increase linearly with the applied potassium rates, approximately $20 \%$ with $200 \quad \mathrm{~kg} \mathrm{ha}^{-1}$ $\mathrm{K}_{2} \mathrm{O}$ compared with the control treatment, in a dystrophic Typic Haplustox with a sandy loam texture and low potassium content in the Brazilian Cerrado.

2. Potassium rates increase the potassium content in stalks, but do not affect sugar contents and other cane quality variables.

3. Potassium application methods (planting furrow, side-dressed, and split) show no effect on stalk and sugar yields, on leaf and stalk nutrient contents, and on the evaluated cane quality variables.

\section{References}

ALMEIDA, H.J. de; CRUZ, F.J.R.; PANCELLI, M.A.; FLORES, R.A.; VASCONCELOS, R. de L.; PRADO, R. de M. Decreased potassium fertilization in sugarcane ratoons grown under straw in different soils. Australian Journal of Crop Science, v.9, p.596604, 2015

BRAGA JUNIOR, R.L. do C.; LANDELL, M.G. de A.; SILVA, D.N. da; BIDÓIA, M.A.P.; SILVA, T.N. da; THOMAZINHO JÚNIOR, J.R.; SILVA, V.H.P. da; ANJOS, I.A dos. Censo varietal IAC de cana-de-açúcar no Brasil - Safra 2017/18 e na Região Centro-Sul - Safra 2018/19. Campinas: Instituto Agronômico de Campinas, 2019. 64p. (Série Tecnologia APTA. Boletim técnico IAC, 221).

COLETI, J.T.; CASAGRANDE, J.C.; STUPIELLO, J.P.; RIBEIRO, L.D.; OLIVEIRA, G.R. de. Remoção de macronutrientes pela cana-planta e cana-soca, em Argissolos, variedades RB83486 e SP81-3250. STAB - Açúcar, Álcool e Subprodutos, v.24, p.32$36,2006$.

CONSECANA. Conselho dos Produtores de Cana-de-açúcar, Açúcar e Álcool do Estado de São Paulo. Manual de instruções. 5.ed. Piracicaba, 2006. 111p. 
DONAGEMMA, G.K.; FREITAS, P.L. de; BALIEIRO, F. de C.; FONTANA, A.; SPERA, S.T.; LUMBRERAS, J.F.; VIANA, J.H.M.; ARAÚJO FILHO, J.C de; SANTOS, F.C. dos; ALBUQUERQUE, M.R. de; MACEDO, M.C.M.; TEIXEIRA, P.C.; AMARAL, A.J.; BORTOLON, E.; BORTOLON, L. Characterization, agricultural potential, and perspectives for the management of light soils in Brazil. Pesquisa Agropecuária Brasileira, v.51, p.1003-1020, 2016. DOI: https://doi.org/10.1590/ s0100-204x2016000900001.

ENERGÉTICA SERRANÓPOLIS LTDA. Departamento Agrícola. Dados Climáticos: Serranópolis. Serranópolis, 2017. Base de Dados em Pims.

FERREIRA, D.F. Sisvar: a guide for its bootstrap procedures in multiple comparisons. Ciência e Agrotecnologia, v.38, p.109-112, 2014. DOI: https://doi.org/10.1590/S1413-70542014000200001.

FLORES, R.A.; ANDRADE, A.F. de; CASAROLI, D.; QUIRINO, D.T.; ABDALA, K. de O.; MARTINS, C.; BUENO, A.M.; ALVES JÚNIOR, J.; EVANGELISTA, A.W.P. Potassium fertilization in sugarcane ratoon yield grown in a tropical region. Communications in Soil Science and Plant Analysis, v.51, p.896-910, 2020. DOI: https://doi.org/10.1080/00103624.2020.1744622.

FLORES, R.A.; PRADO, R. de M.; PANCELLI, M.A.; ALMEIDA, H.J.; MODA, L.R.; BORGES, B.M.M.N.; SOUZA JUNIOR, J.P. de. Potassium nutrition in the first and second ratoon sugarcane grown in an Oxisol by a conservationist system. Chilean Journal of Agricultural Research, v.74, p.83-88, 2014. https://doi.og/10.4067/S0718-58392014000100013.

GARCIA, J.C.; BONETI, J.E.B.; AZANIA, C.A.M.; BELUCI, L.R.; VITORINO, R. Fontes de adubação potássica na lixiviação de potássio em Neossolo Quartzarênico. Revista Eletrônica Thesis, ano12, p.76-89, 2015.

IBGE. Instituto Brasileiro de Geografia e Estatística. Produção Agrícola Municipal. Available at: <https://sidra.ibge.gov.br/ pesquisa/pam/tabelas $>$. Accessed on: July 22020.

KAMINSKI, J.; MOTERLE, D.F.; RHEINHEIMER, D. dos S.; GATIBONI, L.C.; BRUNETTO, G. Potassium availability in a Hapludalf soil under long term fertilization. Revista Brasileira de Ciência do Solo, v.34, p.783-791, 2010. DOI: https://doi.org/10.1590/S0100-06832010000300020.

LANA, R.M.Q.; ZANÃO JÚNIOR, L.A.; KORNDORFER, G.H.; MACIEL JUNIOR, V.A. Parcelamento da adubação potássica na cana-planta. STAB - Açúcar, Álcool e Subprodutos, v.23, p.28$31,2004$.

LEITE, J.M.; CIAMPITTI, I.A.; MARIANO, E.; VIEIRAMEGDA, M.X.; TRIVELIN, P.C.O. Nutrient partitioning and stoichiometry in unburnt sugarcane ratoon at varying yield levels. Frontiers in Plant Science, v.7, art.466, 2016. DOI: https://doi.org/10.3389/fpls.2016.00466.

LUZ, P.H. de C.; QUINTINO, T.A.; SILVA, F.C. da; COLETI, J.T.; BET, J.A. Nutrição mineral e fertilização em cana-de-açúcar. In: SILVA, F.C. da; ALVES, B.J.R.; FREITAS, P.L. de. Sistema de produção mecanizada da cana-de-açúcar integrada à produção de energia e alimentos. Brasília: Embrapa, 2017. v.2, p.656-730.
MALAVOLTA, E.; VITTI, G.C.; OLIVEIRA, S.A. Avaliação do estado nutricional de plantas: princípios e aplicações. 2.ed. Piracicaba: Potafos, 1997. 319p.

ORLANDO FILHO, J.; ZAMBELLO JUNIOR, E. Influência da adubação NPK nas qualidades tecnológicas da cana planta, variedade CB41-76. Brasil Açucareiro, v.96, p.37-44, 1980.

OTTO, R.; ALTARUGIO, L.M.; SANCHES, G.M. Atualizações sobre exigências nutricionais da cana-de-açúcar para fins de manejo da adubação. Informações Agronômicas, n.3, p.1-10, 2019.

OTTO, R.; VITTI, G.C.; LUZ, P.H. de C. Manejo da adubação potássica na cultura da cana-de-açúcar. Revista Brasileira de Ciência do Solo, v.34, p.1137-1145, 2010. DOI: https://doi.org/10.1590/S0100-06832010000400013.

PANCELLI, M.A.; PRADO, R. de M.; FLORES, R.A.; ALMEIDA, H.J. de; MODA, L.R.; SOUZA JUNIOR, J.P. de. Growth, yield and nutrition of sugarcane ratoon as affected by potassium in a mechanized harvesting system. Australian Journal of Crop Science, v.9, p.915-924, 2015.

RAIJ, B. van. Fertilidade do solo e manejo de nutrientes. Piracicaba: International Plant Nutrition Institute, 2011. 420p.

RAIJ, B. van; CANTARELLA, H.; QUAGGIO, J.A.; FURLANI, A.M.C. (Ed.). Recomendações de adubação e calagem para o Estado de São Paulo. 2.ed. Campinas: Instituto Agronômico, 1996. 285p. (IAC. Boletim técnico, 100).

REIN, T.A.; SOUSA, D.M.G. de; SANTOS JÚNIOR, J. de D.G. dos; NUNES, R. de S.; KORNDÖRFER, G.H. Manejo da adubação fosfatada para cana-de-açúcar no cerrado. Planaltina: Embrapa Cerrados, 2015. 12p. (Embrapa Cerrados. Circular técnica, 29).

REIS JUNIOR, R. dos A. Probabilidade de resposta da cana-deaçúcar à adubação potássica em razão da relação $\mathrm{K}+\left(\mathrm{Ca}^{2+}+\mathrm{Mg}^{2+}\right)$ ${ }^{0,5}$ do solo. Pesquisa Agropecuária Brasileira, v.36, p.1175-1183, 2001. DOI: https://doi.org/10.1590/S0100-204X2001000900011.

ROSSETTO, R.; DIAS, F.L.F.; LANDELL, M.G.A.; CANTARELlA, H.; TAVARES, S.; VITTI, A.C.; PERECIN, D. $\mathrm{N}$ and $\mathrm{K}$ fertilisation of sugarcane ratoons harvested without burning. In: INTERNATIONAL SOCIETY OF SUGARCANE TECHNOLOGISTS CONGRESS, 27., 2010, Veracruz. Proceedings. Veracruz: ISSCT, 2010a. v.27, p.1-8.

ROSSETTO, R.; DIAS, F.L.F.; VITTI, A.C.; TAVARES, S. Potássio. In: DINARDO-MIRANDA, L.L.; VASCONCELOS, A.C.M. de; LANDELL, M.G. de A. (Ed.). Cana-de-açúcar. Campinas: IAC, 2010b. p.289-312.

ROSSETTO, R.; SPIRONELlO, A.; CANTARELlA, H.; QUAGGIO, J.A. Calagem para a cana-de-açúcar e sua interação com a adubação potássica. Bragantia, v.63, p.105-119, 2004. DOI: https://doi.org/10.1590/S0006-87052004000100011.

SANTOS, H.G. dos; JACOMINE, P.K.T.; ANJOS, L.H.C. dos; OLIVEIRA, V.A. de; LUMBRERAS, J.F.; COELHO, M.R.; ALMEIDA, J.A. de; ARAUJO FILHO, J.C. de; OLIVEIRA, J.B. de; CUNHA, T.J.F. Brazilian soil classification system. $5^{\text {th }}$ ed. rev. and exp. Brasília: Embrapa, 2018. E-book. Available at: $<$ http://ainfo.cnptia.embrapa.br/digital/bitstream/item/181678/1/ 
SiBCS-2018-ISBN-9788570358219-english.epub>. Accessed on: Apr. 142020.

SILVA, F.C. da (Ed.). Manual de análises químicas de solos, plantas e fertilizantes. 2.ed. Brasília: Embrapa Informação Tecnológica; Rio de Janeiro: Embrapa Solos, 2009. 627p.

SILVEIRA, J.A.G. da; CROCOMO, O.J. Efeitos de nitrogênio e potássio na utilização de nitrato e distribuição de carboidratos em cana-de-açúcar. Pesquisa Agropecuária Brasileira, v.26, p.24257, 1991.
SOUSA, D.M.G. de; LOBATO, E. (Ed.). Cerrado: correção do solo e adubação. 2.ed. Brasília: Embrapa Informação Tecnológica; Planaltina: Embrapa Cerrados, 2004. 416p.

UCKER, F.E.; DE-CAMPOS, A.B.; HERNANI, L.C.; MACÊDO, J.R. de; MELO, A. da S. Movimentação vertical do íon potássio em Neossolos Quartzarênicos sob cultivo com cana-de-açúcar. Pesquisa Agropecuária Brasileira, v.51, p.1548-1556, 2016. DOI: https://doi.org/10.1590/S0100-204X2016000900054. 